\title{
THE GRAFFITI OF TIKAL, GUATEMALA
}

\author{
Michael KAMPEN \\ Arizona State University
}

Graffito (plural, graffiti) derives from the Italian "graffito" meaning scratch or scribble. Art historical studies outside the area of Maya studies have traditionally distinguished graffiti from more formal types of writing, drawing and painting. Likewise, in Tikal, on the basis of formal style or technique, the architectural graffiti are separable from what appear to be the more deliberately conceived and valued forms of art, the material upon which most of the art history of Tikal will be written.

Maya graffiti are among the least recognized and poorest preserved of the Maya modes of drawing and painting. The incised, gouged punctuate, painted and printed architectural graffiti of Tikal represent the largest known collection of Maya graffiti. Architectural graffiti is distinguished here from other forms of graffiti appearing on portable objects such as shells, ceramics and obsidians found in Tikal. Many of the centers listed in Chart 1 are represented by a single graffito and some major Maya art centers are conspicuously absent from this list. Maya graffiti have not been carefully recorded and an undetermined number of centers not included in Chart 1 may have unreported graffiti. Graffiti, in fact, appear to be a common and expectable feature of Maya centers; they appear almost everywhere that plaster walls, vaults and floor surfaces are preserved and searched specifically for graffiti. The lack of any concentrated survey and research into the distribution of Maya graffiti, their relationship to Maya art and the meaning graffiti might have in the reconstruction of Maya civilization, is reflected in the few brief and dispersed references to Maya graffiti in the bibliography on Maya art.

The presently known graffiti in Tikal may represent a small fraction of the total amount of graffiti originally produced in Tikal. Graffiti on the exterior surfaces of structures, being especially vul- 


\section{Chart 1: Maya Centers with Reported Graffiti}

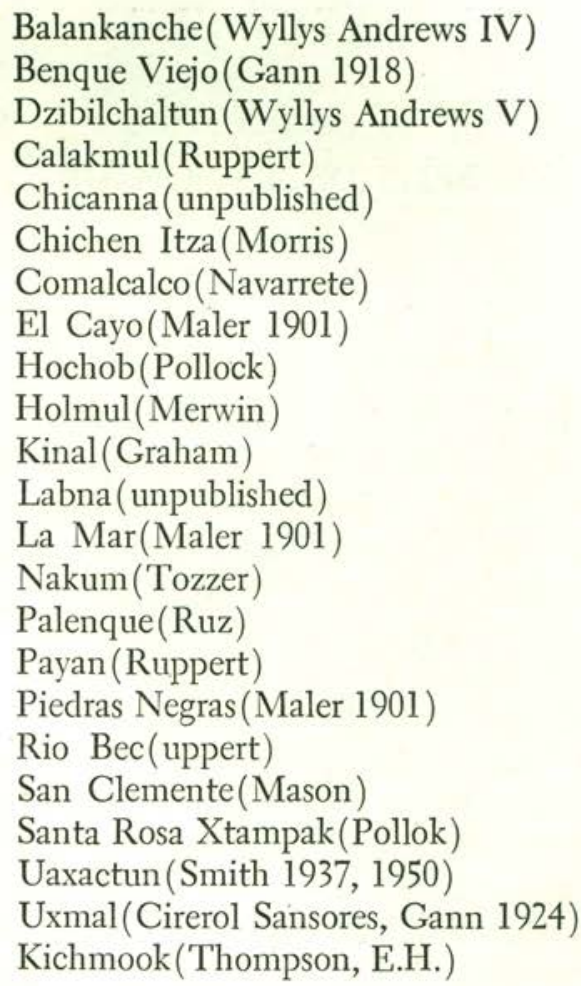

nerable to weathering, would have been very short-lived. After the abandonment of Tikal centuries of weathering continued to reduce the number of graffiti, even in the sheltered, interior architectural locations. Much of the plaster has crumbled from the walls of structures including cases where the vaults are still intact. The seepage of rain water through the ruined structures, the growth of roots and burrowing animals have worked together to destroy much of the fragile plaster and its graffiti.

\section{Technical varieties of graffiti}

The ten technical varieties of graffiti listed below are divided into four groups: cut, painted, printed and composite. Black paintings and positive prints are separated from negative prints. Composite graffiti combine two individual varieties in a single context. 
The distribution of the technical varieties is given in Chart 2 and the dates of all structures bearing graffiti are listed in Chart 3. Incised graffiti, being found in all structures bearing graffiti and in all time periods, are not included in the chart.

A. Cut graffiti: Incised, gouged and punctate varieties

1. Incised

Quantity: Over $90 \%$ of the known griffiti in Tikal are incised.

Technique: Shallow lines cut by sharp objects, presumedly flakes of obsidian or flint, vary from less than $1 \mathrm{~mm}$. to about $5 \mathrm{~mm}$. Lines never appear to be retraced.

Technical Associations: Incised graffiti have much narrower lines than gouged graffiti. The resemblance to incised obsidians is superficial and will be discussed with artistic style.

Composite Forms: With gouged, punctate and painted varieties. With one exception, all composite forms include the incised technique.

Structures: All structures bearing graffiti include the incised variety. Incised graffiti are found in every structural location known to bear graffiti.

Chronological Context: Incised graffiti are found in all periods.

Comments: Incised graffiti are more easily executed than painted varieties and the other cut graffiti. Except for the black and red painting techniques, incised graffiti are somewhat more representational than the other varieties. The facility and representational advantages combined may explain why incised graffiti account for more than $90 \%$ of the known graffiti in Tikal.

2. Gouged

Quantity: Less than $1 \%$ of the known graffiti in Tikal are gouged.

Technique: Broad areas of the plaster are cut away to outline simple images. The technique is distinguishable from incisions and the recessed gouges are indicated in the illustrations by stippling. 
Composite Forms: Gouged graffiti can be used in context with the incised varieties and in one instance, appears with punctate graffiti.

Structures: See Chart 2. The most complicated examples are in

Str. 5D-91. All known examples occur on walls.

Chronological Context: One example in Str. 5D-33-2nd, is Early or Middle Classic, the remainder are Late Classic.

Comments: Gouged graffiti are not highly representational.

3. Punctate

Quantity: Less than $1 \%$ of the known graffiti in Tikal are punctate.

Technique: Round holes are drilled or chipped into the plaster, usually in curved linear sequence.

Technical associations: Punctate graffiti may be made with the same tools or class of tools used to produce the gouged graffiti.

Composite Forms: Punctate graffiti can be used with incised and gouged varieties.

Structures: See Chart 2. Examples are not concentrated in any single structure. All reported examples occur on walls.

Chronological Context: All reported examples are Late Classic.

Comments: The technique appears to be nonrepresentational although the geometric configurations may have specific formal symbolism. Composite examples, with incising, may represent chance or unmeaningful combinations of techniques.

B. Painted graffiti: black and red varieties.

1. Black Paint

Quantity: About $4 \%$ of the known graffiti in Tikal are black paint.

Technique: Black, carbon base paint is applied in linear patterns by a brush or related soft-tipped tool. With the exception of Str. 5D-46, where the lines are highly variable and 
Chart 2: Technical Varieties of Graffiti: Time and Space Distribution

\begin{tabular}{ll}
\hline \hline Structure & Date \\
\hline
\end{tabular}

Gouged Graffiti

3D-40

4E-37

$5 \mathrm{C}-13$

5D-33-2nd

5D-91

$5 \mathrm{E}-51$

$5 \mathrm{E}-58$

Punctate Graffiti

$5 \mathrm{C}-13$

$5 \mathrm{D}-2$

5D-54

5D-91

$5 \mathrm{E}-51$

$5 \mathrm{E}-58$

5G-8

Black Painted Graffiti

3D-40

5D-2

5D-46

5D-52-2nd.

5D-54

5D-91

5D-Sub-3-A

Red Painted Graffiti

3D-40

Printed Graffiti

4E-37

$6 \mathrm{~F}-27$
Late Classic

Late Classic

Late Classic

Early-Late Classic

Late Classic

Late Classic

Late Classic
Late Classic

Late Classic

Late Classic

Late Classic

Late Classic

Late Classic

Late Classic

Late Classic

Late Classic

Early Classic

Early or Middle Classic

Late Classic

Late Classic

Preclassic

Late Classic 


\begin{tabular}{ll}
\hline \hline Structure & Date \\
\hline
\end{tabular}

Composite Incised-Gouged Graffiti

4E-37

$5 \mathrm{C}-13$

5D-33-2nd

5D-91

$5 \mathrm{E}-51$

$5 \mathrm{E}-58$
Late Classic

Late Classic

Early-Late Classic

Late Classic

Late Classic

Late Classic

Composite Incised-Punctate Graffiti

$\begin{array}{ll}5 \mathrm{C}-13 & \text { Late Classic } \\ 5 \mathrm{D}-2 & \text { Late Classic } \\ 5 \mathrm{D}-54 & \text { Late Classic } \\ 5 \mathrm{D}-91 & \text { Late Classic } \\ 5 \mathrm{E}-51 & \text { Late Classic } \\ 5 \mathrm{E}-58 & \text { Late Classic } \\ 5 \mathrm{G}-8 & \text { Late Classic }\end{array}$

Composite Gouged-Punctate Graffiti

5E-58

Late Classic

Composite Incised-Black Painted Graffiti

5D-52-2nd

Early Classic

Composite Incised-Red Painted Graffiti

3D-40

Late Classic

many lines are very thin, this technique uses mainly thick outlines with little interior detailing. Lines may be retraced or made with closely juxtaposed dabs.

Technical Associations: The only examples of red paint represent disks or circles so it is not possible to make a meaningful comparison of these two logically related techniques. Black paint graffiti are related mainly by material and possible means of application to 
the wall and tomb paintings in Tikal which represent subject matter unlike the graffiti.

Composite Forms: Aside from what appear to be accidental superimpositions, black paint is not combined with other technical varieties of graffiti.

Structures: The relatively few examples of this variety are widely dispersed throughout Tikal. Not all examples are on walls: a graffito in Str. 5D-2 is in a roof comb chamber and a graffito Str. 5D-91 is on the vault.

Chronological Context: Black painting appears in every period and is especially plentiful before the Late Classic.

Comments: Considering the small sample of known black paintings the diversity of techniques, structural locations, chronological contexts and represented forms, is relatively greater than any other technical variety.

\section{Red Paint}

Quantity: Only two pairs of red disks are reported at Tikal.

Technique: The pigment appears to be dabbed onto the plaster.

Technical Associations: Black painted graffiti. Not enough red paint graffiti survives to make a detailed and meaningful comparison.

Composite Forms: Lines are incised around the two red disks in Str. 3D-40.

Structures: Only reported examples are in Str.3D-40 where red paint appears on a wall.

Chronological Context: Late Classic.

C. Printed graffiti: Positive and negative varieties.

1. Positive printed graffiti

Quantity: Less than $1 \%$ of the known graffiti in Tikal are positive prints. 
Technique: Hands covered with red pigment are pressed onto architectural surfaces.

Technical Associations: Negative printed graffiti also represent the outlines of hands.

Structures: Not enough examples are recorded to chart a significant distribution among and within structures.

Chronological Context: Late Classic

2. Negative printed graffiti

Quantity: Less than $1 \%$ of the known graffiti in Tikal are negative prints.

Technique: Paint is dabbed around the outline of a hand held on the architectural surface.

Technical Associations: Positive printed graffiti also represent the outlines of hands.

Structures: This variety appears near the bottom of the vault in Str. 5D-1.

Chronological Context: Late Classic.

D. Composite Graffiti: Incised and gouged, incised and punctate, incised and black paint, incised and red paint, gouged and punctate.

1. Incised and Gouged

Quantity: The relatively large number of composite examples in Chart 2 may contain an untold number of unintentional combinations.

Technique: In most examples the incising and gouging appear to contribute to separable images and do not combine to represent the same form of the set of forms.

Structures: See Cut graffiti, Gouged (A2).

Chronological Context: See Cut graffiti, Gouged (A2).

2. Incised and punctate (See Cut graffiti, Punctate)

3. Incised and Black Paint (See Painted graffiti, Black Paint)

4. Incised and Red Paint (See Painted graffiti, Red Paint)

5. Gouged and Punctate graffiti (See Cut graffiti, Gouged) 
The structural contexts and dates of graffiti are given in Chart 3. Graffiti were cut, painted or printed on almost every visible structural surface: approximately $95 \%$ of the reported graffiti are located on interior walls, about $2 \%$ are located on benches and roughly $3 \%$ occur on floors, vaults and in roof comb chambers. Graffiti in exterior locations may have been more common than the present sampling suggests. The rare record examples were preserved on the sealed and protected exterior walls of few excavated, buried structures. Many graffiti are found near the floor and clustered around benches, in locations where persons may have been seated. Graffiti, in general are not distributed in discernible formal patterns derived from the structural formats of their architextural settings nor are they necessarily concentrated in areas of maximum visibility for persons entering rooms or passing through the interior spaces.

The distribution of graffiti in Tikal poses some problems. Why, for example, are so many more graffiti found in Str. 5D-2 (Temple II) than in Str. 5D-1 (Temple I) which is directly across the Central Plaza? Str. 5D-3 (Temple III) is devoid of graffiti except for a sketchy example found in a roof comb chamber. And why is 5D-65 so much more heavily laden with graffiti than other structures in the Central acropolis, some of which have no reported graffiti? Not all structures have been opened and searched specifically for graffiti and the uneven destruction of plaster, affecting some structures more than others, can account in part for the irregular distribution of the graffiti.

All of the techniques of workmanship described above are defined as graffiti because they share two important features: they are all found on the plaster surfaces of architecture but they do not appear to be integrated into those architectural contexts. The architectural graffiti clearly do not appear to be fundamental or integral parts of their contexts. The lack of integration between the graffiti and their associated structures will be discussed with style qualities. Tomb paintings and wall paintings, such as those on 5D-sub-10-1st, are formally integrated with their architectural contexts. Tomb paintings in general, although often sketchily executed and loosely organized on the walls, are apparently deliberate and functional parts of the tomb iconography. Graffiti, on the other hand, need separate treatment because they are scattered across the architectural sufaces without being organized by frame boundaries, columns or rows and they do not reflect the outlines of the architectural contexts. The combination of the two qualify- 
Chart 3: Structures Bearing Graffiti and their Dates

\begin{tabular}{ll}
\hline \hline Structure & Date \\
\hline 6F-27 & Late Classic \\
5G-8 & Late Classic \\
5G-4 & Late Classic \\
5E-58 & Late Classic \\
5E-51 & Late Classic \\
5D-95 & Late Classic \\
5D-91 & Late Classic \\
5D-65 & Late Classic \\
5D-61 & Late Classic \\
5D-54 & Late Classic \\
5D-52-1st & Late Classic \\
5D-51 & Late Classic \\
5D-50 & Late Classic \\
5D-49 & Late Classic \\
5D-43 & Late Classic \\
5D-38 & Late Classic \\
5D-26-1st & Late Classic \\
5D-20-1st & Late Classic \\
5D-3 & Late Classic \\
5D-2 & Late Classic \\
5D-1 & Late Classic \\
5C-49 & Late Classic \\
5C-13 & Late Classic \\
4E-45 & Late Classic \\
4E-37 & Late Classic \\
3D-43 & Late Classic \\
3D-40 & Late Classic \\
5D-32-1st & Middle Classic \\
5D-52-2nd & Early or Middle Classic \\
5D-33-2nd & Early Classic \\
5D-46 & Early Classic \\
5D-32-2nd & Early Classic \\
5D-sub-10-1st & Preclassic \\
5D-sub-3-A & Preclassic \\
5D-sub-1-1st & Preclassic \\
5D-26-4th & Preclassic \\
5D-23-1st & Preclassic \\
\hline & \\
&
\end{tabular}


ing ideas, architectural placement and disregard for the schema of the architectural design suggest that the technical varieties of graffiti discussed above share certain features or ideas that necessitate their being studied together, distinct from the nonarchitectural graffiti and other forms of art associated with their architectural contexts.

Chronological Context: The earliest possible dates for the production of graffiti are determined by the construction and burial dates of their structural contexts (Chart 3). The archaeological context of sealed structures allows us to date the burial of those structures, providing good terminal dates for the associated graffiti. Terminal dates for graffiti outside Tikal are rare: Classic masonry was set over graffiti in Structure IV, Room 2, at Rio Bec (Ruppert, 1943, p. 36) and at Uaxactun, Tzacol sherds were found in the rubble filling Room 2, Structure BXIII, burying the graffiti there by Tepeu times (Smith, 1950, 1958). Five Pre-Classic, 2 Early Classic and one Early of Middle Classic structure bearing graffiti at Tikal were still sealed when they were first examined. Considering the small number of sealed structures predating the Late Classic that have been excavate, the number of examples bearing graffiti is relatively high, suggesting that graffiti was plentiful prior to the Late Classic and that large quantities of graffiti were produced throughout the history of architectural construction at Tikal.

But the majority of structures with graffiti at Tikal are Late Classic and were never sealed: most of them remained totally or partially open up to the present day and their graffiti could have been added at any time after the construction dates of their associated structures. The fact that Maya graffiti do not have the typical Classic Maya stylizations, and the knowledge that the structures in which the graffiti appear were not sealed, led many observers to assume that the graffiti were Post Classic, rather meaningless scribbles left there by visitors and squatters in the centuries after the abandonment of Tikal. Graffiti were considered to be of little or no value in the study of Classic Maya art and civilization.

The methods of determining style dates defined by T. Proskouriakoff, 1950, require works of art with many more details, particularly vestments, than we find in the graffiti. Certain graffiti have obvious parallels with other Tikal subjects but they can not be given precise dates on the basis of style to refine the dates provided by the archaeological record. 


\section{Formal Style}

Graffiti are not generally recognized as works of art. Most writers on Maya art and civilization have failed to mention the graffiti, and others have attributed the graffiti to bored novices (Thompson, 1954, pp. 10, 11), those not yet trained in the finer points of Maya civilization, or to Post Classic persons having already forgotten the same (Morley, 1956, p. 239). The wide range of quality in the graffiti at Tikal was noted by Edwin Shook (1958, p. 16) and by Lester Walker (1959, pp. 194-195 and 1965, pp. 15-19). Walker divided the graffiti of Tikal into two categories: small human figures with precise detailing and large, cruder graffiti representing fantastic animals.

A definition of style, as that terms applies to the graffiti and explains its formal characteristics, is necessary to help explain the possible reasons for the production of graffiti in Tikal. Graffiti do not necessarily qualify as finished works of art by the standards associated with other Tikal media. In terms of style, graffiti relate closely to our modern, Western idea of a rough sketch. Lines are rendered with relative quickness and little concern for their absolute descriptive accuracy. Unlike most of the other arts of Tikal, graffiti do not have complicated curves: most lines are straight or simply curved and they lack the complexity of the forms they illustrate. Line junctures and crossing are seldom rendered with the degree of illustrative accuracy common in other varieties of formal composition in Tikal. The graffiti compositions are not tightly controlled and have a tendency to sprawl across the architectural spaces without frames to limit and structure their formal composition. It is difficult to tell where one graffito ends and another begins. One graffito may also be superimposed on what appears to be another separable graffito. It is not always possible to distinguish a graffito from the maze of lines comprising the graffiti that completely cover some of the architectural surfaces. Are these superimpositions haphazard, resulting from the reuse of the architectural surfaces without regard for the presence of the pre-existing graffiti or are the superimpositions intentional? The very casual or unplanned qualities of graffiti suggest that there was very little concern for the formal relationship of one graffito to another and that the majority of juxtapositions and superimpositions are accidental or unintentional. 
The problem of reading the justapositions and superimpositions on a single heavily inscribed architectural surface is well illustrated in Structure 5D-65. Graffiti on three walls surround a large bench represent at least 10 juxtaposed and overlapping scenes plus many inserted motifs. While it is tempting to assume that a familiarity with Maya art allows us to isolate each graffito from the graffiti, it is dangerous to do so. Without frames or borders we can not be certain how much of each composition was envisioned as an extended scenic context by the persons producing the graffiti.

The sketchy qualities already noted in the lines, linear connections, image compositions and contextual relationships of one graffito to another, are expressed in the seemingly illogical combination of incised graffiti with gouged, punctate and painted varieties. In most instances the two technical varieties do not work together to create the same imagery.

Along with the superimpositions of separable scenes and dissimilar techniques, no other artistic media in Tikal finds expression in such variable or inconsistent scales as does the graffiti. Examples of scale disjunctions, resulting from superimpositions, are so common in the graffiti that they are expectable. A figure superimposed over a ball court scene in Structure 5D-43 is roughly 30 times as large as the ball players. In 5D-52-2nd, a seated, crosslegged figure with folded arms, is incised within the chin and shoulder area of a larger painted figure in same, reversed pose.

Considering the relatively crude, or anti-technical nature of the graffiti execution, it seems highly unlikely that such complicated scale changes and image relationships could be intentionally conceived. In summary, on every stage of conception and execution, the graffiti appear to lack the logical and organized principles of construction characterizing other varieties of Maya art. While the thematic content of the graffiti in Late Classic structures expands that of known graffiti from earlier periods, the basics of the formal style change little from the Early Classic period onward, except in a few isolated instances where Post Classic Mexican stylizations occur (Chart 4). Graffiti in six structures are attributed to the Post Classic period on the basis of several style or formal characteristics: the presence of certain non Classic Maya lines, compositions, grotesques and facial profiles. The regularized pattern of straight lines, simplified curves and highly organized, repititious rhythms reflect a significant knowledge of a non-Maya, specifically highland Mexican, art style. Other graffiti demonstrate some of these same qualities but to a lesser degree. The total number of examples with 
possible Mexican stylizations is significantly larger than these major examples. Decorative, grotesques head forms are composed from a limited number of non-Classic Maya line types, mostly straight lines and simple curves with much formal repetition, illustrating highly complex characters of non-Classic Maya variety. Some of the best preserved and most obviously non-Classic Maya facial types have relatively flat vertical profiles with short, blunt noses and bulbous nostrils.

Chart 4: Graffiti with nonclassic Maya Stylization

Structure

Structures 3D-40

3D-43

$5 \mathrm{C}-13$

5D-54

5D-65

$6 \mathrm{~F}-27$

Graffiti and the Desecration of Abandoned Structures

This concluding section contains data to support two closely related conclusions:

1. That graffiti in the Late Classic structures are associated with the Eznab period (A. D. 850-925) and were affixed to those structures after they had been abandoned and no longer functioned in their traditional capacity under Classic rulership.

2. That graffiti on sealed structures, predating the Late Classic period, were produced in the terminal stages of those structures existence when they were no longer functioning in their traditional capacities and were essentially abandoned.

If the graffiti were clearly parts of the structural contexts in which they occur, we might assume that they were part of the thinking and time periods that produced the rest of the architecture and its decorations. But the style of the graffii suggest that they 
are not fundamental or integral parts of the structures on which they appear, nor do graffiti relate closely to any aspect of the arts in Tikal. The fact that certain themes and motifs of Late Classic art appear in the graffiti in no way proves contemporaneity. The very low degree of correlation between the formal and nonformal content of Tikal art in general, and the graffiti, argues against the necessity of placing the graffiti in a time context with other arts in Tikal. It is difficult to find any reason to suggest that graffiti might be constructive additions to the art programs in Tikal, or that the graffiti are works by Tikal artists. The fact that the graffiti in Late Classic structures are so entirely outside any aristic context as we understood it, suggest that the graffiti could belong to the Eznab period.

Eznab pottery has been reported in about half the structures bearing graffiti. Not all the excavation materials have been fully studied at present and it is possible that Eznab sherds could have been removed from some structures before the beginning of the excavations. The presence of Eznab remains in a given structure need not be a necessary conditions for the production of graffiti because graffiti could have been produced by persons entering unoccupied rooms.

Who was responsible for the production of the graffiti? They are not the works of professionally trained artists: the technical level of proficiency is generally low and even the finest examples do not measure up to the Late Classic standards of Tikal art. Were the persons producing the graffiti untrained artists operating outside the ancient Classic traditions of art at Tikal, adding their own graffiti images and ideas to the structures of the city they now occupied?

While the graffiti in unsealed Late Classic structures may be Eznab, the work of persons from out side the historical context of Tikal, this does not explain the presence of graffiti in earlier structures sealed before Eznab times. Graffiti on pre-Late Classic structures are technically and stylistically related to graffiti attributed to the Eznab period. But, they must be explained in terms of activities occurring within the context of pre-Classic and Classic Tikal history.

It is possible that the structures sealed before Eznab times received their graffiti as part of the terminal activities associated with their abandonment, desecration and razing which took place before they were sealed by later constructures. This period of time, after such structures were no longer occupied and operated 
in a traditional fashion, and before they were sealed, represents a period of abandonment, a time in some ways comparable to that period when structures were abandoned in the Eznab period.

Archaeological information relating to terminal period activities in structures bearing graffiti will only be summarized here to illustrate a few basic ideas associated with the desecration of certain excavated structures predating the Late Classic period. Pits dug in the floor and burnings within Structures 5D-sub-1-1st and 5D-sub3A (PreClassic) may have been part of their ritual desecration at about the time their graffiti was affixed. An accumulation of debris in Structure 5C-23-1st, before it was sealed, suggest that it was abandoned for an undetermined period of time before it was finally buried. Structure 5D-33-2nd razed in the Late Classic, is a major source of information about terminal stage activities. A number of events, the excavation for Burial 23, the destruction of Altar 19, the movement and destruction of other monuments, including Stela 31 which was broken and reset in this structure, the burning of Stela 31 and smashing of censors in this room represent desecration ceremonies. Some debris was allowed to accumulate in the Structure before it was further desecrated and sealed by the construction of 5D-33-1st. It is possible that the graffiti were incised some time in this terminal period.

Terminal activities in the structures listed above appear to differ from the earlier occupational activities. The time span and number of distinct steps in the terminal periods are not clear. We may be dealing with ceremonies that lasted anywhere from a period of a few days to many months. Archaeological evidence produced to date does not disprove that structures may have been allowed to remain abandoned for significant periods of time, long enough for the reported graffiti to have accumulated. It is also not clear whether the graffiti were added casually or intentionally, as planned parts of the terminal activities. Since it is possible that razed structures were abandoned for some time before the task of rebuilding began, it is possible that graffiti may have been affixed after the terminal activities had ceased and it may have been produced by persons other than those involved in the ceremonies of desecration. Graffiti could have been added to the remains of the structures as a further means of destruction, or added very casually, without being intended as part of the terminal or post terminal ceremonies.

The beginning of the Eznab period graffiti marks a major rupture in the history of Tikal. Applying this logic to sealed struc- 
tures, it is possible that they also receive much of their graffiti after major historical breaks, with changes of rulers of dynastic changes.

Captions for figures 1-8 to go with "The Graffiti of Tikal". All drawingsafter photographs and earlier drawings by this author.

FIGURE 1. Structure 5D-65(Maler's Palace). Detail of extensive incised graffiti representing variations of the enthronement scene with protector figures.

Figure 2. Structure 5D-65(Maler's Palace). Two incised dancers. The left figure is one of the finest examples of known graffiti in Tikal. A careful examination of the figure, however, will reveal that the artist lacked the professional skills of the Classic painters and sculptors in Tikal.

Figure 3. Structure 5D-2(Temple 2). Incised sacrifice scene representing a victim, impaled by a spear and tied to two upright poles on a low platform. Two ritual attendants to the right hold stone knives set in curved wooden handles.

Figure 4. Structure 5D-43. Five incised figures set in a ball court context with a large game ball. These players are part of a panoramic landscape that includes flanking temples, a stela and an altar. The lines selected for this illustration have been extracted from a thick network of superimposed incisions.

Figure 5. Structure 3D-40. Detail of an extensive graffiti representing a large jaguar near a flying figure of a man wearing a headdress of bee forms. The two figures may not necessarily be part of a planned context.

Figure 6. Structure 3D-43. Gouged image of a bird with a foreshortened beak. This subject may be copied after Classic prototypes.

FIGURE 7. G Group. Sacrificial victim with his chest opened illustrating the ritual of human sacrifice by heart extraction.

Figure 8. G Group. Tikal temple with single door and clearly defined lintel. Representations of architectural details are common in the graffiti of Tikal. Here the artist has attempted to illustrate the architectural sculptures on the roof comb and upper facade of a temple. 


\section{BIBLIOGRAPHY}

Acosta, Jorge R.

"La Doceava Temporada de Exploraciones en Tula, Hgo.," 1960, Anales del Instituto Nacional de Antropología e Anders, Ferdinand Historia. Vol. XIII, No. 42, pp. 29-58. México.

Berlin, Heinrich

"El Templo de las Inscripciones - VI- de Tikal," Antropología e Historia de Guatemala, Ministerio de Educación Pública, Vol. III, No. 1, enero, 1951, pp. 33-54.

Cirerol Sansores, Manuel

Guía de Ushmal, segunda edición, Mérida, Yucatán 1956.

Coe, William R.

"Two Carved Lintels from Tikal," Archaeology, Vol. II, No. 2, Summer, 1958, pp. 75-80.

Coe, William R.

Tikal, A Handbook of the Ancient Maya Ruins, The University Museum, University of Pennsylvania, Philadelphia, 1967.

Davidson, Marshall B.

Ed., The Horizon Book of Lost Worlds, American Heritage Publishing Co., New York, 1962.

Fernández, Miguel Ángel

"Las Ruinas de Tulum II", Anales del Instituto Nacional de Antropología e Historia, Tomo I, pp. 95-121.

GanN, Thomas

"The Maya Indians of Southern Yucatan and Northern British Honduras," Smithsonian Institution Bureau of America Ethnology, Bulletin, 64, Washigton, 1918.

GanN, Thomas

In an Unknown Land, Charles Scribners, Sons, Southampton, 1924.

Gann, Thomas

Maya Cities, Camelot Press, 1927.

Graham, Ian

Archaeological Explorations in El Peten, Middle American Research Institute, Tulane University, New Orleans, Pub. No. 33, 1967.

Harrison, Peter D'Arcy

The Central Acropolis, Tikal, Guatemala: A Preliminary Study of the Function of its Structural Component During the Late Classic Period, Ph.d Dissertation, Department of Anthropology, University of Pennsylvania, 1970. 
Kubler, George

Maler, Teobert

The Art of Tikal, Tikal Report 39 (unpublished).

Explorations in the Department of Peten Guatemala,

Memoirs of the Peabody Museum of American Archaeology and Ethnology, Harvard University, Cambridge, Vol.

Maler, Teobert V, No. 1, 1911-1913.

Researches in the Central Portion of the Usumatsintla Valley, Memoirs of the Peabody Museum of American Archaeology and Ethnology, Harvard University, Cam-

Mason, Gregory bridge, Vol. II, No. 1, 1901-1903.

Maudslay, Alfred P.

South of Yesterday, Henry Holt and Co., New York, 1940.

Biologia Centrali-Americana, Vol. III, Plates, London, 1889-1902.

Merwin, Raymon E. and Vaillant, George C.

The Ruins of Holmul Guatemala, Memoirs of the Peabody Museum of American Archaeology and Ethnology, Harvard University, Cambridge, Vol. III, No. 2, 1932.

Morley, Sylvanus Griswold

The Ancient Maya, 3rd edition, Stanford University Press, Stanford, 1956.

Morris, Earl H., Charlot, Jean and Morris, Ann Axtell

The Temple of the Warriors at Chichen Itza, Yucatan, Carnegie Institution of Washington, Vol. I, Pub. 406, 1931.

Navarrete, Carlos

"Los Ladrillos Grabados de Comalcalco, Tabasco," Boletin del Instituto Nacional de Antropología e Historia, Pollock, H.E.D. No. 27; pp. 19-25. México.

"Architectural Notes on Some Chenes Ruins," Monographs and Papers in Maya Archaeology, William R. Bullard, Jr., ed., Papers of the Peabody Museum of Archaeology and Ethnology, Harvard University, Cambridge, Vol. 61, pp. 1-87.

Proskouriakoff, Tatiana

A Study of Classic Maya Sculpture. Carnegie Institution of Washington, Publication 593, Washington.

Ruppert, Karl and Denison, Jr. John N.

Archaeological Reconnaisance in Campeche, Ouintana

Roo and Peten, Carnegie Institution of Washington, Pub.

Ruz Lhuillier, Alberto 543, Washington, 1943.

"Exploraciones en Palenque: 1950," Anales, Instituto Nacional de Antropologia e Historia, Secretaría de Educación Pública, Tomo V, No. 33, 1951, pp. 25-45. 
Satterthwaite, Linton

"Maya Practice Stone-carving at Piedras Negras," Expedition, Vol. 7, No. 2, Winter, 1965, pp. 9-18.

SHook, EdwIN M.

"Investigaciones Arqueológicas en las Ruinas de Tikal, Departamento de El Peten, Guatemala," Anthropologia e Historia de Guatemala, Ministerio de Educación Pública, Vol. III, No. 1, enero, 1951, pp. 9-32.

SHook Edwin M.

Tikal Report No. 1: Field Director's Reports; The 1956 and 1957 Seasons, the University Museum, University of

Smith, A. LeDYARD Pennsylvania, Museum Monographs, Philadelphia, 1958.

Structure A-XVIII, Uaxactun, Contributions to American Archaeology, Carnegie Institution of Washington, Washington, Vol. IV, No. 20, Pub. 483, 1937.

Smith, A. LeDyard

Uaxactun Guatemala: Excavations of 1931-1937. Carnegie Institution of Washington, Washington, Pub. 588-1950.

Smith, Robert E.

Ceramic Sequence at Uaxactun Guatemala. Middle American Research Institute, Publication No. 20, 2 Vols.; New Orleans.

Thompson, Edward H.

"Ruins of Xkichmook, Yucatan," Publications of the Field Columbian Museum, Anthropological Series, Vol. II, No. 3, Chicago, July 1898, pp. 209-230.

Thompson, J. ERic S.

The Rise and Fall of Maya Civilization, University of Oklahoma Press, Norman, 1954.

WALKer, JR., Lester

"Maya Graffiti as Art," Art in the South, Southwestern Louisiana Journal, Vol. 3, No. 4, Lafayette, 1959.

WALKER, JR., LESTER

"A Message from the Maya," Americas, Oct., 1965, pp. 15-19.

Webster, Helen T.

"Tikal Graffiti," Expedition, The Bulletin of the University Museum of the University of Pennsylvania, Phi-

Wyllys ANDrews IV, E. ladelphia, Vol. 6, No. 1, Fall, 1963, pp. 36-47.

Balankanche, Throne of the Tiger Priest, Middle American Research Institute, Tulane University, New Orleans, Pub. No. 32, 1970.

No Author

Neuvelles Archieves des Missions Scientifiques et Literaries Choix de Rapports et Instructions, Nouvelle Serie, Fascicule 4, Paris, 1911. 


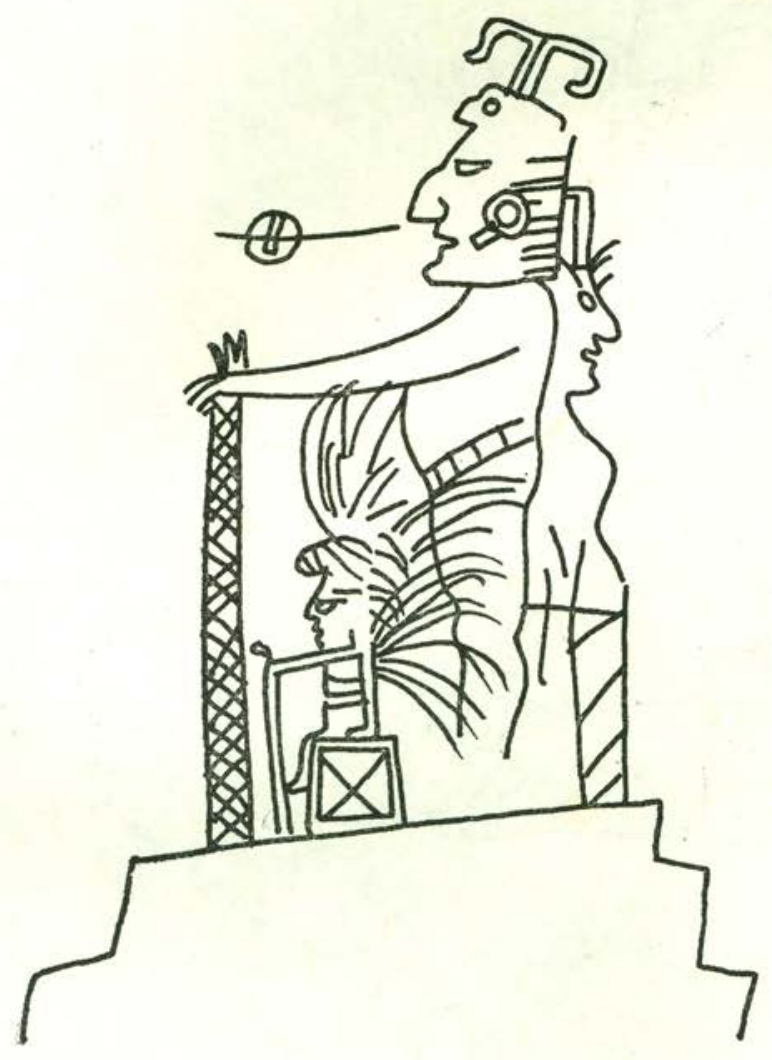



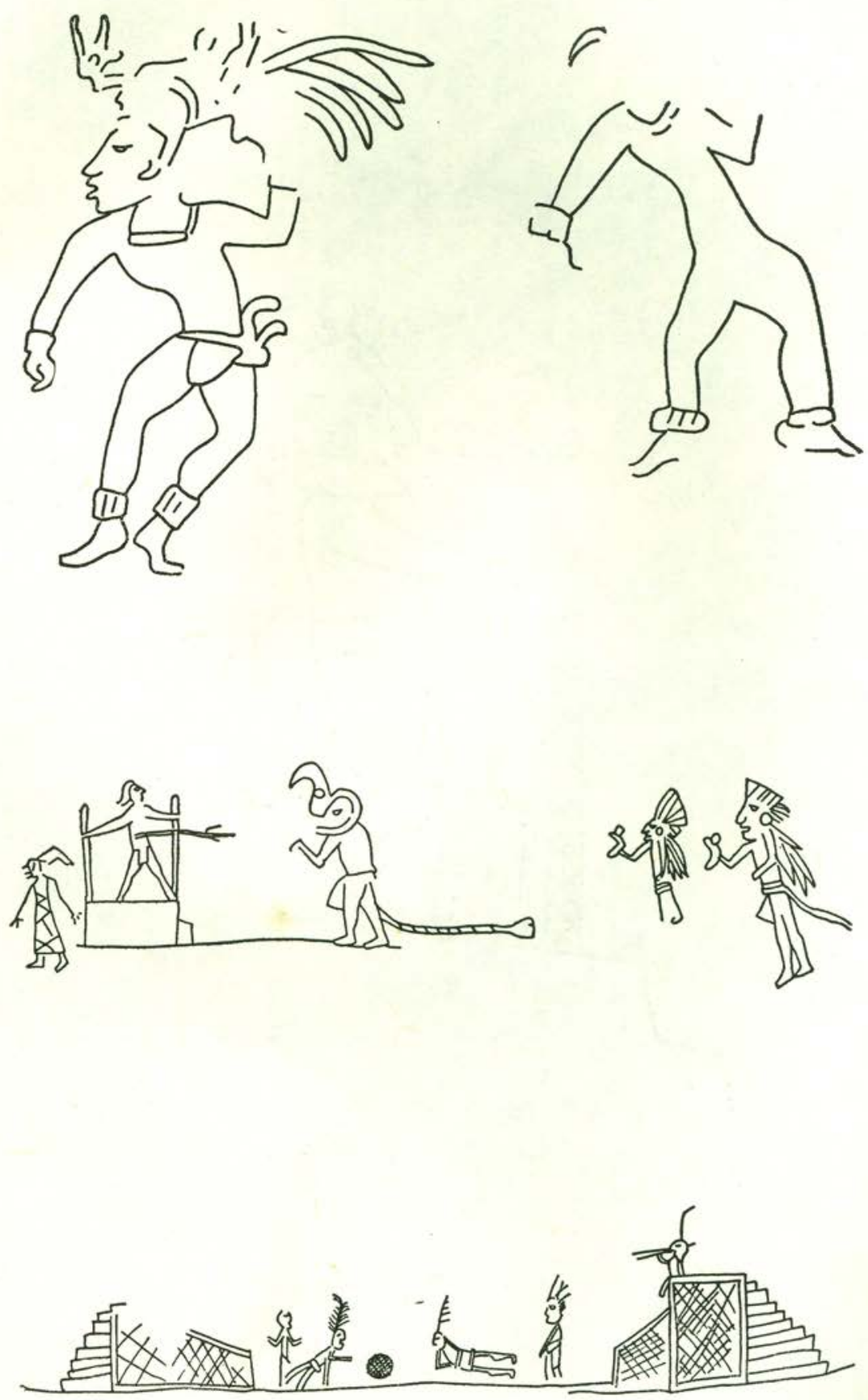

Estudios de Cultura Maya. Vol. XI, 1978

Instituto de Investigaciones Filológicas/

Centro de Estudios Mayas, UNAM

http://www.iifilologicas.unam.mx/estculmaya/ 


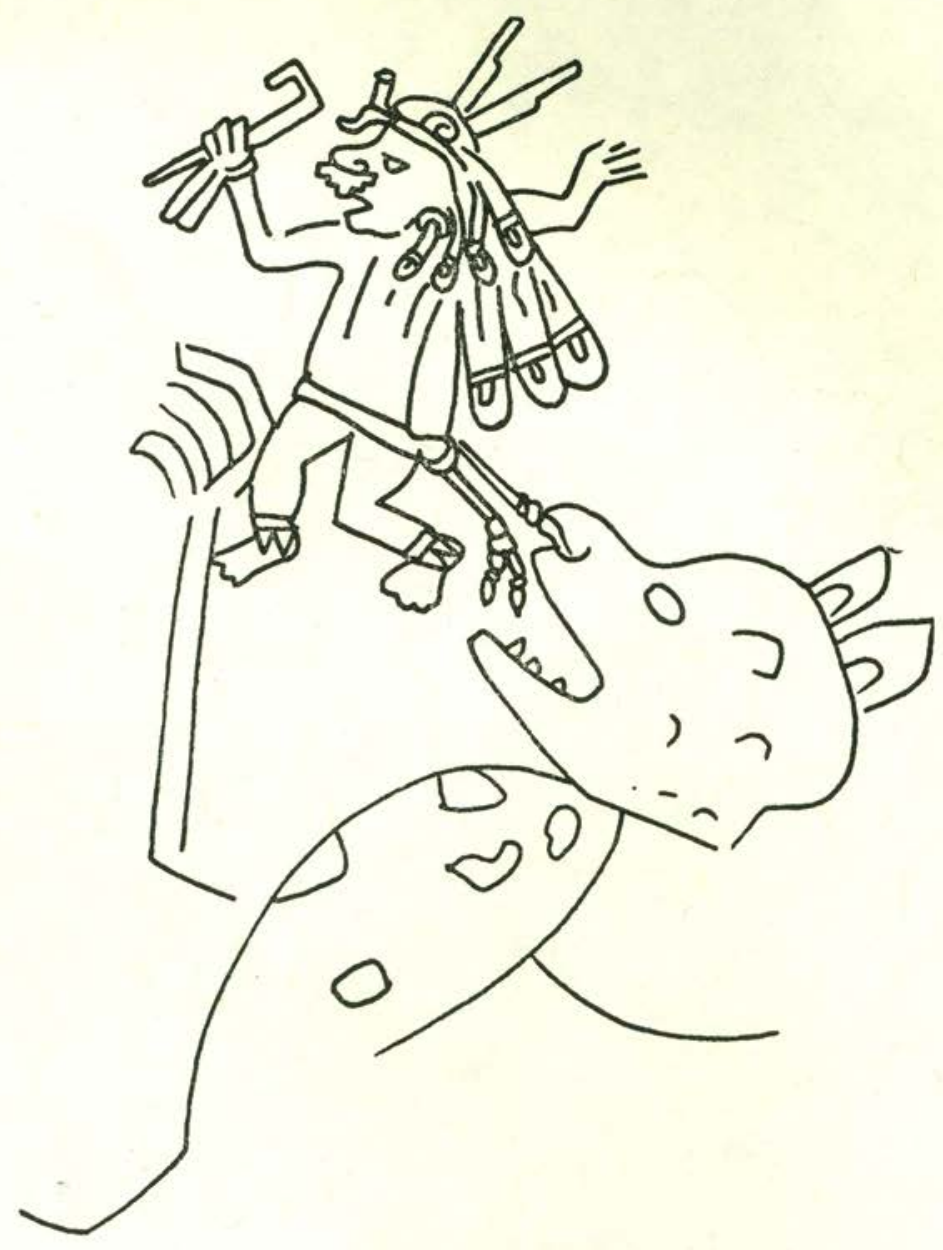

Estudios de Cultura Maya. Vol. XI, 1978

Instituto de Investigaciones Filológicas/

Centro de Estudios Mayas, UNAM

http://www.iifilologicas.unam.mx/estculmaya/ 


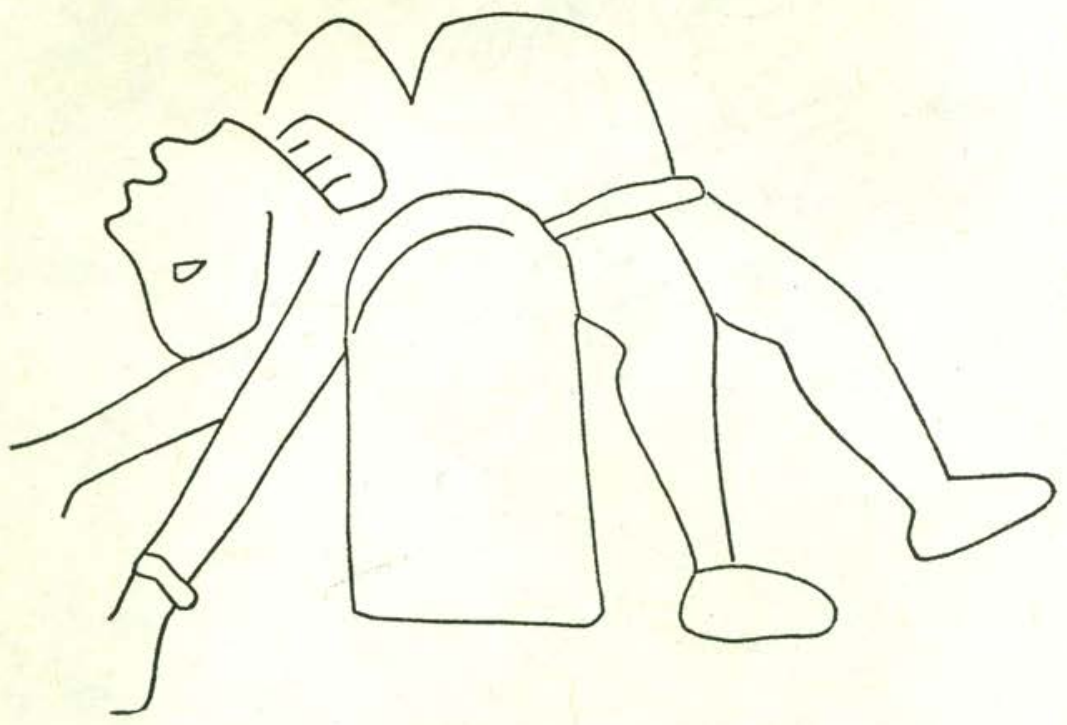

Estudios de Cultura Maya. Vol. XI, 1978

Instituto de Investigaciones Filológicas/

Centro de Estudios Mayas, UNAM

http://www.iifilologicas.unam.mx/estculmaya/ 



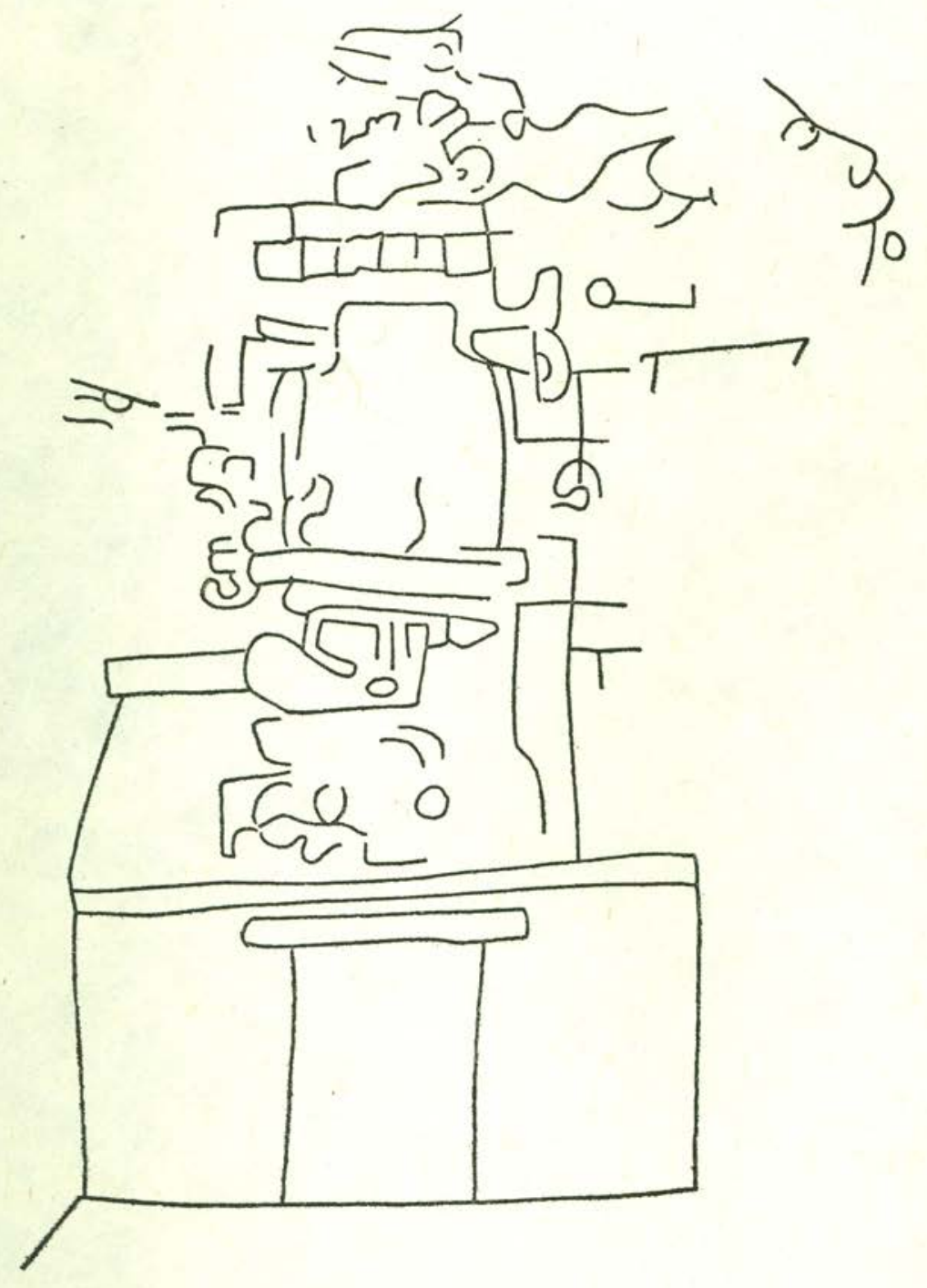

Estudios de Cultura Maya. Vol. XI, 1978

Instituto de Investigaciones Filológicas/

Centro de Estudios Mayas, UNAM 